\title{
PFKFB3 Gene
}

National Cancer Institute

\section{Source}

National Cancer Institute. PFKFB3 Gene. NCI Thesaurus. Code C102808.

This gene plays a role in carbohydrate metabolism. 